\title{
The Recognition of Brazilian samba de roda and Reunion maloya as Intangible Cultural Heritage of Humanity
}

\section{Guillaume Samson and Carlos Sandroni}

\section{Abstract}

In this essay, we present a comparative analysis of the UNESCO heritage nomination process for two African Diaspora music and dance forms: samba de roda, from the Bahian Recôncavo (a coastal area of the northeastern Brazilian state of Bahia), and maloya, from Reunion Island (a former French colony in the Indian Ocean, which is now officially an "overseas department of France"). Samba de roda, as the Brazilian candidate, was included in the III Proclamation of Masterpieces of the Intangible Heritage of Humanity, in 2005. And maloya, the French candidate, was inscribed onto the Representative List of the Intangible Cultural Heritage of Humanity, in 2009. Despite a number of formal commonalities between samba de roda and maloya, such as responsorial singing, choreography, and the main musical instrument types, the controversies raised during their respective processes of nomination were quite distinct. The former is regarded as a traditional and less well known style of samba, the musical genre widely recognized as the musical emblem of Brazil. The latter competes with séga-a genre of popular music consolidated in the local media - for the position of chief musical representative of Reunion Island. The disparate symbolic identities attributed to these musical expressions pave the way for a distinct manner of employing the international resources related to the safeguarding of intangible heritage. This suggests that the local impact of the inclusion onto international lists depends as much on the contextual particularities of each candidacy as on central decision-making bodies such as UNESCO. 
Keywords: Samba de roda; Maloya; Bahia (Brazil): Music and dance; Reunion (France, overseas departement): Music and dance; Intangible cultural heritage; Cultural policies.

\section{Resumo}

Este artigo apresenta uma análise comparativa do processo de patrimonialização, junto à UNESCO, de duas formas de música e dança afro-diaspóricas: o samba de roda, do Recôncavo baiano (área litorânea no estado da Bahia, na região Nordeste do Brasil), e o maloya, da Ilha da Reunião (um ex-colônia francesa no Oceano Índico, cujo atual estatuto jurídico-político é o de um "Departamento francês do Ultramar"). O samba de roda foi incluído, como candidato brasileiro, na Terceira Declaração de Obras-Primas do Patrimônio Imaterial da Humanidade, em 2005. O maloya foi inscrito, como candidato francês, na Lista Representativa da Convenção para a Salvaguarda do Patrimônio Imaterial, em 2009. Embora apresentem muitos traços formais em comum - tais como canto responsorial, estilo de dança e principais instrumentos musicais de acompanhamento - o samba de roda e o maloya diferem no que diz respeito às controvérsias suscitadas por seus respectivos processos de patrimonialização. O primeiro é visto como uma versão tradicional e menos conhecida de um gênero mais amplo, o samba, geralmente reconhecido como principal emblema musical do Brasil. O segundo disputou com o séga, gênero de música popular consolidado na mídia local, o papel de principal representante musical da Ilha da Reunião. Tais diferenças no simbolismo identitário atribuído a formas musicais dão lugar a diferentes usos dos recursos internacionais de salvaguarda do patrimônio imaterial. Sugerese que o impacto político local de tais inscrições em listas internacionais depende de particularidades contextuais de cada candidatura, tanto quanto de instâncias decisórias centrais como a UNESCO.

Palavras-chave: Samba de roda; Maloya; Bahia (Brasil): Música e dança; Ilha da Reunião (França): Música e dança; Patrimônio cultural imaterial; Políticas culturais comparadas. 


\section{The Recognition of Brazilian samba de roda and Reunion maloya as Intangible Cultural Heritage of Humanity}

Guillaume Samson and Carlos Sandroni

\section{Introduction}

To what extent does recognition of musical forms as Intangible Cultural Heritage (ICH) relate to national politics and local identity struggles? What is revealed by the ways in which cultural expressions are selected as candidates for inclusion in international Proclamations and Lists? What is the impact of these choices, in which governments appear to play a central role (Roda, 2011), on musical practices and their contexts? To address these questions, this article examines comparatively the complex processes of recognition by UNESCO as ICH of humanity of two African Diaspora dance and music cultural expressions, samba de roda from Brazil and maloya from Reunion Island. In particular, we explore the dynamics of local politics and emotional investment regarding the respective traditions while also considering the ways in which such traditions have been reevaluated locally in the context of international recognition.

It is important to note that we, the authors of this article, each participated individually as ethnomusicologists in the respective commissions which were established to compile the applications sent to UNESCO on maloya and samba de roda. Based on our experiences, we will first examine the relationships between the ICH processes and regulations, how they are implemented institutionally, and the diversity of cultural and political contexts in which

1 Samba de roda was recognized by the Proclamation of Masterpieces of the ICH on November 25, 2005, and maloya was formally added to the ICH Representative List on October 1, 2009. Audiovisual information about samba de roda is available at http://www.unesco.org/culture/ich/?RL=00101 and about maloya at http://www.unesco.org/culture/ich/RL/oo249. 
musics are eligible for recognition. Second, we will discuss the role of cultural expertise in these processes of cultural revitalization, considering such questions as: 1) Should we think of the investment of UNESCO and the ICH as something akin to a set of tools employable by communities in order to assert their right to difference in a globalized world? 2) Or, on the contrary, should the ICH policies be regarded as a new means of "inventing traditions," resulting in top-down constructions imposed on the people they supposedly represent? Between these two positions, the first of which can be described "as too naïve" and the other "too critical" (Sandroni, 2010), we have above all sought, through our analyses, to underscore the complexity and diversity of local cultural and historical situations that can be affected by UNESCO's designation of the ICH status.

\section{Samba de roda and Maloya: Some Elements of Historical and Cultural Comparison}

\section{1 “Neo-African” Musics}

A comparison between maloya and samba de roda seems pertinent for several reasons. Both developed in the analogous socio-economic and cultural contexts of nineteenth-century colonial sugar cane plantation societies. Defined by forced African migration as a result of the slave trade and, beginning in 1848 for Reunion Island, indentured servitude, maloya (in what is considered its "traditional" form in the Island) and samba de roda belong to what Peter Manuel (1989: 25) has characterized as "neo-African" New World musics. According to this model, both maloya and samba de roda are defined by songs involving alternating responsorial (i.e., call-and-response) singing between a soloist and a choir, and are performed with the accompaniment of orchestras composed mainly of drums and rattles. They also share choreographic practices in which couples of dancers move either in succession or simultaneously inside a circle of participants or assistants. Dance moves themselves are also similar, composed of "short, quick steps" (Chaudenson, 1974 for maloya; Waddey, 1981 for samba de roda) that shuffle along the ground. Finally, maloya and samba de roda have historically comprised a sort of "common cultural denominator" as part of a cluster of religious, economic, and ludic practices specific to plantation workers. Until the 1960 o on Reunion Island, the musical 
practices currently associated with maloya were common across a variety of contexts that integrated ancestor worship, work songs (linked to the cultivation of sugar cane), entertainment practices (such as the bal maloya), and a form of combat-dance called moring (Samson, 2008). In the Reconcavo region of Brazil, samba de roda is typically associated with entertainment practices, but it is also a part of syncretic cults dedicated to Catholic saints, in the AfroBrazilian Candomblé religion, and in the combat-dance practice called capoei$r a$. In their historical performance contexts and formal characteristics, maloya and samba de roda both appear to share significant attributes. In fact, musicians in Reunion occasionally invoke their shared traits as explanations for the appeal of samba and Brazilian musical culture in general on the island. ${ }^{2}$

\subsection{Different Musical Contexts of Recognition}

A comparison between the contemporary expressions of these musical genres helps to shed light on the ways in which both genres were seen as consistent with the value system of the ICH. But if we take the comparison a step further, a more sociological perspective on their respective contexts reveals several fundamental differences that strongly influenced the path to, and the consequences of, recognition by UNESCO. These differences relate to the position of the musical forms recognized by the ICH in their respective fields of cultural production (Bourdieu, 1998). In the case of maloya, the entire genre was recognized, including its many varieties - "traditional," "neo-traditional," "electric". Like maloya, samba in fact encompasses a diverse group of categories that includes samba-enredo, samba de partido alto, and samba de roda, among others. But the ICH award came to one particular version of this much larger samba genre. Because they play different roles in their respective societies and relate to national musical identities in unique ways, this distinction between maloya and samba de roda has important implications for their ICH designation.

\subsection{The Emergence of Samba as the Brazilian National Music}

Samba serves as a powerful symbol of national identity in Brazil, rarely questioned as such to date. Its rise to the status of "Brazil's national music" took

2 Along the same lines, the cultural ties between moring of the Reunion Island and Brazilian capoeira were exploited during the revitalization of moring in the 1990 . 
place during the 1930s. The first published instances of the word "samba" in reference to music or dance date from the 1830 in Brazil. In 1842, the word appeared for the first time in Bahia to describe the practices of enslaved Africans. Beginning in the 1860s, however, it became increasingly common in print sources to refer to the music and dance practices of slaves, as well as of free blacks, mulattos, and poor whites. In the ensuing decade, references to "sambas" in the Bahian press share several characteristics with the present-day samba de roda of the Recôncavo. The subsequent popularization of the word in Rio de Janeiro was associated with the immigration of Bahian blacks to the capital immediately after slavery was abolished in 1888 . There are also several early twentieth-century references to popular celebrations in Rio de Janeiro during which samba was practiced.

Recording technology first arrived in Rio de Janeiro (the capital at the time) in 1902 and played a key role in the popularization of samba. Musical genres such as lundu, modinha and choro gradually became part of an emergent industrial and commercial network in which the music was diffused as merchandise via records and later, through radio broadcasts. The creation of samba as a genre of popular music was part of this broader process. The success of the song "Pelo telefone" during the 1917 Carnival was an early milestone. Allegedly composed by Ernesto dos Santos, aka Donga, the son of a Bahian woman from the city of Santo Amaro (in the Recôncavo), "Pelo telefone" was described as a "samba carnavalesque." It is worth noting, however, that some members of the Bahian community of Rio de Janeiro accused Donga of appropriating collective musical heritage for his own purposes (Sandroni 2001).

In the 1920s, the spread of samba throughout Rio was facilitated by a variety of media, and it eventually was acknowledged as the country's national musical genre in the 1930s. "Samba carioca", which developed in Rio and later spread throughout the country, evolved a style that was very distinct from Bahian samba de roda. The "nationalization" of samba took place against a backdrop of profound social and political changes and increased attention to the question of national identity (Vianna, 1995). During the twentieth century, this came to involve the question of the different "races" from which the Brazilian people originated. According to a view that was prevalent among the early-twentieth-century political and intellectual elite, racial mixing doomed the nation because it was perceived as a form of degeneration that 
would cause the country to lag "behind" Europe and the United States. The massive influx of whites from Europe between the 1890 and the 1930 s was thus perceived as the only means of counter-acting the negative effects of racial mixing (Skidmore, 1993; Schwarcz, 1993).

Between the 1920 and 1930s, the "modernist" literary generation, together with culturalism-influenced sociologists such as Gilberto Freyre, radically inverted this relationship with mestiçagem by reframing it as a positive attribute. From that point forward, mestiçagem was interpreted as proof of the tolerant, harmonious character of Brazilian society (Freyre, 1997 [1933]). Since then, mixing has even come to be seen as a kind of prophecy about the cultural creativity of Brazilians. Indeed, Brazilians have often been portrayed as open to unexpected blends, continually searching for hybrid solutions to daily problems and to spiritual matters (Ribeiro et al, 1996). Towards the end of the 1930s, the promotion of mestiçagem, albeit often tainted by thinly-veiled racism, came to dominate official discourse as well as the media. Samba thus came to be perceived as the popular musical genre that best expressed Brazilian "racial mixing" and indeed, as an example "par excellence" of Brazilian cultural creativity. This was particularly well expressed by the celebrated samba "Aquarela do Brasil," composed in 1939 by Ari Barroso (known in English as "Brazil”). The lyrics of the song, which was hugely successful in Brazil and internationally, describe Brazil as a "mulatto" country, "brown," "tanned” ("mulato, moreno, trigueiro"), a "land of samba and tambourines" ("terra de samba e pandeiro"); the song's references to skin tones that were neither completely "white" nor totally "black" were inextricably linked to musical topoi.

From the 1940 s to the early twenty-first century, Brazilian music saw the popularization of several other successful musical genres, such as baião, bossa-nova, $i \hat{e}-i \hat{e}-i \hat{e}, M P B$, and axé, but, for most Brazilians, none ever rivaled the more-or-less official position of samba as "the most Brazilian of musics."

\subsection{Competition Between Maloya and Séga on Reunion: The Question of Legitimacy}

Compared with samba, maloya has a substantially more ambivalent relationship with the musical identity of Reunion Island and has been the object of considerable controversy. Having first appeared in the public and media discourse in the 1970s, maloya has been involved in an on-going tugof-war for representativeness with séga, a Creole musical form. On Reunion, 
the distinction between séga and maloya became established in the second half of the twentieth century (Samson, 2008). The distinction divided the field of musical creation on the island into two principal genres that, although closely related in historical and musical terms, were nevertheless often perceived as opposed to each other in terms of cultural representativeness. A key factor in this division relates to the terminological distinction between séga and maloya.

The term séga first appeared in the late seventeenth century in the Mascarene Islands, and along with its variants, tchéga and shiega, continued to have multiple meanings well into the mid-twentieth century. In colonial travel narratives and journals, the term was used to describe all of the musical practices of laborers of African and Malagasy origin, including slaves, descendants of slaves, and indentured servants. Beginning in the 1850 - 1860 , the term was also applied to Creolized forms of quadrille and popular singing. First mentioned in the early nineteenth century, the term maloya appears to have come into widespread use beginning in the 1920 s to refer to the music of the descendants of slaves and indentured servants of African and Malagasy origin (music that had been labeled séga in colonial documents until that time). This hypothesis, widely accepted since the pioneering studies of JeanPierre La Selve (1995), should be interpreted carefully, however. Until the 1960s, a wide range of diverse, local terminologies (romans, kabaré, maloya, chanson maloya, chanson kabaré, séga maloya...) appear to have been used to describe the musical traits ascribed to the broad category of maloya music ." (Chaudenson, 1974; Samson, 2008).

In the second half of the twentieth century, two movements helped cement the polarized distinction between the terms séga and maloya: 1) beginning in the 1950s, the media popularized Creole popular songs called séga by way of recordings and talent shows, a development that was partly propelled by the folklore movement; 2) beginning in the 1970s, in a militant leftist political context, plantation laborers' "traditional" musical practices were revitalized under the exclusive label of maloya. Partially reflecting conflicting views of the island's political and cultural ties to France, including debates regarding the island's autonomy, the opposition between séga and maloya was constructed during the 1970s. Séga came to function to some extent as a symbol of collusion with the right-wing anti-autonomist establishment, while maloya embodied cultural and political resistance to assimilation with 
France, a position politically identified with the left-wing pro-autonomy movements and the Parti Communiste Réunionnais (PCR). Although it is partly valid, this polarized view of séga and maloya oversimplifies the occasionally blurred boundaries between the two genres. Séga musicians, some of whom were themselves PCR militants, had contacts with maloya beginning in the late 1950s. Conversely, some maloya singers recorded séga versions (i.e., with modern orchestras) of songs that are more typically associated with maloya. Finally, in the mid-197os, séga and maloya musicians occasionally shared the same stage.

The evolution of maloya as a totally distinct musical genre dates from this period, however. In the 1980s and 1990s, the institutional recognition of the genre by cultural policies helped it become part of the national and international live performance circuit and World Music scene. Séga remained confined to the local and regional market, however, much more present than maloya on the island's airwaves and album sales charts. The economic role and pathways of diffusion of séga and maloya are grafted onto contrasting cultural positionings. While séga lyrics tend to refer to daily life, humor, anecdotes, and popular criticism, since the 1970s maloya has been more closely associated with complex and occasionally contradictory themes involving memorial revitalization, the return to ancestral roots, and the literary and musical avant-garde.

As a consequence of this process of differentiation since the 197os, séga and maloya currently occupy very different positions within the island's cultural field. Their roles as the twin musical emblems of Reunion, which are sustained by the media, the recording industry, official institutions, and the live music scene, creates a sort of competition between them. And the process of selecting a single genre as representing the island's culture - a sole "winner", implying "one country, one culture, one people, and thus one music" - resulted in a strong tendency to mask the ties between the two musics and the complementarity of their respective fields of expression.

\section{The ICH and Collective Representativeness}

Dominant ideas about collective musical identity appear to powerfully influence the reception of official forms of recognition of musical genres within their societies and cultural fields. The recognition of samba de roda and 
maloya by UNESCO elicited very different local reactions, which serve to underscore the relative and "localized" dimension and contrasting character of $\mathrm{ICH}$ procedures.

\subsection{Samba and the ICH Proclamation: From \\ Representativeness to the Risk of Extinction}

In these early years of the twenty-first century, samba continues to function as the emblematic national musical genre of Brazil. This was the clear message of a televised report on April 23, 2004 that aired on the Globo network's Jornal Nacional, the most influential news broadcast in Brazil. ${ }^{3}$ Broadcast on what is the Catholic feast day of Saint George, the report presented images of popular devotion to the saint while emphasizing the importance of samba as a national symbol. The relationship between the two subjects-Saint George and samba — gradually became clear as the images succeeded each other. First, the devotion to Saint George is considered particularly strong among samba practitioners and fans in Rio, who associate him with Ogun, a Candomblé "orixá," and Ogun Beira-Mar, the spiritual entity of Umbanda (another popular religion in Brazil). Moreover, April 23 allegedly corresponds with the birth date of Tia Ciata, or "Aunt" Ciata, a key figure in the early development of samba. The broadcast concluded with the announcement of a major decision related to samba, which had been made by the Minister of Culture, the musician Gilberto Gil. The televised announcement read as follows:

"Samba and devotion to a warrior saint are united on this day, April 23, in Rio de Janeiro. Today is Saint George's day, and musicians and composers of samba have commemorated the birthday of the Bahian cook, "Aunt" Ciata, who made samba into a national symbol. (...) Samba is born of a mixture of drums and faith. It is for this reason that the Minister of Culture, Gilberto Gil, has proposed samba, a symbol of the mixing that has forged the Brazilian soul, as a candidate for recognition as part of the Intangible Cultural Heritage of Humanity. The final choice will be made by UNESCO, the United Nations institution that promotes Education and Culture."

This announcement was followed by an excerpt from an interview with

3 A private telecommunications firm that holds a quasi-monopoly in the Brazilian media. 
the Minister-musician in which he stated that: "We think that samba represents an important dimension of this heritage, perhaps one of the most important dimensions of Brazilian intangible heritage."

This was followed by a declaration by Beth Carvalho, one of the most well known contemporary samba singers:

"Samba is the most representative and the most revolutionary musical genre of the Brazilian people."

Gil's proposal was to submit samba as Brazil's candidate for inclusion in the Third Proclamation of Masterpieces of the Oral and Intangible Heritage of Humanity. The program, which UNESCO began developing in 1998, produced proclamations in 2001, 2003, and 2005. These "Proclamations," which preceded the International Convention for Safeguarding of the Intangible Cultural Heritage (voted in 2003 and ratified in 2006), were the first concrete steps taken by UNESCO to widely promote the ICH. Each member country was allowed to present a single candidate for each round. Among the requirements for candidacies, in addition to intrinsic cultural excellence, was the "risk of extinction" - as UNESCO called it—of the cultural practices in question. In fact, the Proclamation's goal was not merely to promote remarkable cultural forms, but also to highlight the cultural importance of candidates considered to be "endangered". The criteria for the selection of "candidates" were as follows:

a. "its outstanding value as a masterpiece of the human creative genius";

b. "its roots in a cultural tradition or the cultural history of the community concerned";

c. "its role as a means of affirming the cultural identity of the peoples and cultural communities concerned, its importance as a source of inspiration and intercultural exchanges and as a means of bringing peoples and communities closer together, and its contemporary cultural and social role in the community concerned";

d. "excellence in the application of the skill and technical qualities displayed";

e. "its value as a unique testimony of a living cultural tradition"; 
f. "the risk of its disappearing, due either to a lack of means for safeguarding and protecting it or of processes of rapid change, or to urbanization, or to acculturation." 4

The criteria can be grouped into three broad areas. Points "a" and "d" concerned the intrinsic quality of the "candidates." Points "b," "c," and "e" related to the relationships between the "candidates" and the cultural traditions among the peoples and "communities" in which they were situated. Point " $\mathrm{f}$ " concerned the risk of extinction. In summary, UNESCO required that potential candidates 1) present intrinsic qualities; 2) be integral parts of the cultural traditions of a community; and 3 ) be threatened with extinction.

Several Brazilian expressions of popular culture could have satisfied these conditions, but samba had the added attribute of a claim to national representativeness. It is nevertheless worth noting that the word "nation" does not appear among the criteria for candidates. The word "people" figures prominently (twice), as does "community" (four times). If the intention was for these terms to be interpreted as signifying "nation," samba was an ideal candidate. After all, compared to similar Brazilian dances such as jongo of the southeastern region or the tambor de crioula of the state of Maranhão, samba was and continues to be widely viewed as a national symbol.

This is not the only possible interpretation of the Proclamation criteria, however. And indeed, as Hafstein (2004) contends with regard to the 2003 Convention (whose general orientation is identical to that of the Proclamation of Masterpieces), it could be argued that this is not the most appropriate interpretation. After all, a cultural form that has acquired some degree of "national representativeness" might for this very reason be incapable of satisfying condition "f," the "risk of extinction." It is also clear that this factor had a negative impact on the candidacy of Argentine tango. Tango was a candidate for the Proclamation in 2003, and the jury reasoned that because it was internationally known, amply recognized by the media, taught in dance schools, and promoted as a tourist attraction, tango was far from facing the risk of extinction.

4 Proclamation of Masterpieces of the Oral and Intangible Heritage of Humanity: Guide for the Presentation of Candidature Files. Paris: UNESCO, 2001, p. 12. Digital version consulted online on April 26, 2013: http:// unesdoc.unesco.org/images/oo12/001246/124628eo.pdf 


\subsection{The Final Choice of the Brazilian Candidate ${ }^{5}$}

The proposal to submit samba as the Brazilian candidate was discussed at the Ministry of Culture at the end of March 2004, and the press announced its candidacy in early April. However, as we shall see, at that point the public treatment of the subject revealed a flagrant misunderstanding of the Proclamation's requirements. During the months of April and May, the Ministry consulted with experts and researchers. It was at this point that I (Carlos Sandroni) was invited to contribute. I had published a book on samba (Sandroni, 2001) that had received favorable coverage in the Brazilian press. For this reason, IPHAN (the Brazilian institution for cultural heritage) invited me to join the project team in early May 2004. As a result, I participated in the discussions that led the Ministry to decide, on June 9, that the Brazilian candidate would not be "Brazilian samba" in general but "samba de roda of the Bahian Recôncavo."

This decision was based on two arguments. The first concerned the requirement of point " $\mathrm{f}$ " of the Proclamation regulations. The risk of extinction of cultural forms, or of entire cultures, has been a frequent and often controversial subject within academic disciplines such as cultural anthropology and ethnomusicology. In the context of political decisions, however, a degree of pragmatism is always recommended. It seemed obvious that it would be difficult to convince the Proclamation jury that "Brazilian samba" met this condition, given its wide diffusion and international prestige (which are comparable to Argentine tango). Indeed, this argument effectively eliminated "Brazilian samba" as a potential candidate.

Numerous other expressions of the intangible Brazilian heritage might also have been credible candidates for the Proclamation's condition " $\mathrm{f}$ " as for the other requirements. For example, it would have been relatively easy to demonstrate the intrinsic value and cultural and community insertion of, as well as the risk of extinction faced by, jongo or tambor de crioula, to which we referred earlier. The final choice of samba de roda is evidence that pragmatism again won the day. The Minister had already announced samba as the candidate, and the press had reported his announcement. The substitution of samba for samba de roda enabled point "f" to be accommodated while also respecting Minister Gilberto Gil's announcement in maintaining a form of "samba" as the Brazilian candidate.

5 On this subject, see also Sandroni, 2011. 
It was not simply a question of terminology, however. The historiography of Brazilian popular music reveals a strong connection between Rio samba and Bahian samba de roda. The latter was in fact often described as the "root" (and Bahia as the "cradle") of Rio samba (or "samba carioca.") The narratives surrounding the origins of samba carioca emphasized the role of Bahian immigration to Rio in festivals and among the Bahian "aunts" such as Ciata, Presciliana (Donga's mother), Amelia (the mother of another celebrated Rio "sambista" named João da Baiana, or "João, son of the Bahian woman"). Samba thus gradually evolved into a new form in Rio de Janeiro and, although scholars such as Alves (2002) and Lopes (1992) have criticized the simplistic nature of these narratives because they do not account for other influences, Bahian samba remains an unavoidable historiographic reference for Rio samba.

Gilberto Gil's initial proposal to apply for ICH recognition of the entire samba genre would have been viable had the candidacy been targeted towards the "Representative List" of the new ICH Convention, which took effect two years after samba de roda was officially recognized. The Proclamation of Masterpieces resembled instead the "List of Cultural Expressions in Danger of Extinction" of the same Convention. The solution that was found--samba de roda--thus represented a compromise between two motivations. One was an expression of Gilberto Gil's desire to promote national identity, and the other related to the fragile nature and risk of extinction of a cultural form. Samba de roda satisfied condition "f " of the Proclamation, while also obliquely satisfying the expectation created among the Brazilian people by the Minister's announcement that the candidate should be "representative of the country." Samba de roda was a credible "representative of the nation" not only because it was "a type of samba," but also because it is the samba form generally considered to be the "origin" or the "source" of Rio samba, which has achieved the status of the musical emblem of Brazil. In addition to the requirements of the UNESCO Proclamation, the exigencies of national self-congratulation were thus also satisfied by the final choice.

When the decision was announced by UNESCO that samba de roda had been designated as a Masterpiece of the Oral and Intangible Heritage of Humanity, the only negative reactions expressed in the press came from individuals who did not understand the regulations of the Proclamation and insisted on the greater representativeness of Rio's samba than Bahian samba; Gilberto Gil's Bahian origins were mischievously cited as an explanation for the final choice of Bahian samba as the Brazilian candidate. 


\subsection{Maloya and the ICH Representative List: From Recognition to Emblematization}

The inclusion of maloya on the ICH representative list was achieved within an institutional context involving a debate about the cultural policies of the Regional Council. The Maison des Civilisations et de l'Unité Réunionnaise ("House of Civilizations and Unity of Reunion", MCUR), whose scientific team was presided over by two academics, Françoise Vergès and Carpanin Marimoutou, was responsible for compiling the application file for the ICH before it was forwarded to the French Ministry of Culture.This policy was a significant feature of the MCUR's principal lines of action, which were designed to contribute to greater cultural equilibrium among the different cultural components of Reunion society. As the title of the preservation project indicated, the objective was to articulate recognition of the cultural diversity of Reunion Island and to unify the island's "people."

These goals can be interpreted as revealing contemporary reinvestment in the processes of Creolization that gave rise to Reunion society. The positive aspects of Creolization are considered to center on a cluster of processes that give rise to new cultural forms by melding together cultures of different origins. In some ways, affirming a program specifically devoted to "Civilizations" and "Unity" expressed a desire to perpetuate the highest achievements of the cultural history of Reunion. This continuity appeared to suggest three narratives that could or ought to coexist: The maintenance of a link with source cultures, the coexistence of these cultural groups within the same geographical space, and the positive value of cultural transfers between these different groups:

"Let's say it again. The unity of Reunion is a unity that must value the fecundity of Creolization as an intercultural practice. It must preserve the ability to integrate, transform, and make its own that which it receives." (MCUR, Pour un musée du temps present [“Towards a Museum of the Present Day"], 2007: 91)

The advocacy for the merits of Creolization by the MCUR guided its approach in terms of culture and heritage, which in turn provided the inspiration and rationale for the building of a new cultural center beginning in 2010. The facility was intended as a modern, living museum that would offer exhibit

6 For a detailed description of this project, see "Pour un musée du temps présent. La Maison des Civilisations et de l'Unité Réunionnaise," which can be consulted on line at the following address: http:/| www.temoignages.re/IMG/pdf/MCUR_POUR_UN_MUSEE-2.pdf 
spaces and research facilities, as well as spaces for performances and debate. Its ultimate purpose was to provide the island's inhabitants with a site that would encourage consciousness-raising, reflexivity, and cultural dialogue.

Given the project's aims to promote cultural tolerance and egalitarianism, it is perhaps surprising that the cultural center aroused powerful opposition. The factors that most directly influenced the reaction to maloya's recognition by UNESCO centered on the emphasis on non-European cultural elements and the "unofficial" heritage of Reunion's population. The leaders of the MCUR and Paul Vergès, president of the Regional Council, made a particular point of these issues, beginning with the organization's very first actions in 2004. The MCUR introduced the question of music very early in the discussions, and in 2004, the title Zarboutan nout kiltir (ZNK) was created as a distinction that would be awarded to honor "the contribution of the women and men of Reunion to the preservation, promotion, creation, and transmission of the intangible cultural heritage of Reunion Island" (MCUR 2009). The first year that the ZNK title was awarded, it recognized the achievements of a maloya musician, Gérose Barivoitse, aka Lo Rwa Kaf ("the Kaffir King"). Four other leading maloya musicians, all claiming African or Malagasy origins, received the ZNK title the following year. This recognition of African cultural contributions to music appears to have been a priority that arose from an understanding of diversity and the goal of focusing on less "official" currents in Reunion's cultural history.

In this respect, the actions of the MCUR followed more or less in the footsteps of PCR cultural militancy in the 1970s. This militancy, including the production of a series of "traditional" maloya recordings, fueled its increasing prominence. Some of these records had a powerful political dimension, blending old songs with speeches, testimony from militants, and songs with lyrics critical of the period's political opponents. Furthermore, Peuple de La Réunion. Peuple du maloya ["People of Reunion. People of Maloya"], one of the LPs recorded during the Fourth Congress of the PCR (1976), emphasized that "every inhabitant of Reunion," whether of African descent or not, could—or should-feel a sense of belonging through maloya, which was becoming a symbolic part of the island's political struggle.

In the post-colonial political context of the 1970s, a period during which independence movements were springing up all over Africa, the PCR was embroiled in a polarized political conflict that pitted its pro-autonomy position 
against right-wing anti-autonomist political forces. In part, pro-autonomy militancy also relied on militancy regarding cultural forms, which symbolized the struggle against colonial oppression whose first victims had been the descendants of slaves and indentured servants. As a consequence of this coalescence between politics and culture, cultural positions, especially with regard to music and language, came to be closely linked to politics. This in turn favored the emergence of an ideology that, as revealed by the conflict surrounding the ICH recognition of maloya in 2009, persisted within the island's cultural and political spheres. The inherent tensions within this ideology are clear: On the one hand, it celebrated métissage (racial mixture) and the desire to embrace Reunion Island as a historic possession of France; on the other hand, was the desire to encourage the diversity of specific historical narratives, leading to the conception of the island's cultural unity that did not emphasize - and even questioned - this very same connection with France. Caught up in this ideological conflict, the promotion of maloya by the PCR in the 1970 greatly contributed to the recognition of African and Malagasy influences as part of the political and cultural identity of the island. It contributed also to the recognition of rites, cults, and the invocations of the ancestors as forces in the island's colonial history. The debate surrounding the recognition of maloya by the ICH is best seen in the context of this political environment.

\subsection{Choosing Maloya: Conflicts and Resentment over Identity Issues ${ }^{7}$}

With the support of the Pôle Régional des Musiques Actuelles ("Regional Organization for Local Contemporary Music", or "PRMA", an organization devoted to support local musicians and producers), the MCUR led the initiative to propose maloya as a candidate for the ICH representative list (according to the new Convention of 2003) and took responsibility for compiling the application materials. As a member of the PRMA team, I (Guillaume Samson) became involved in this process when I was invited to contribute documentation in support of the candidacy. The final draft emphasized the vitality of the genre and its close ties to the musical identity of the island. This approach helped the organization avoid the legitimacy conflicts concerning culture and identity of which maloya had been the focus since it first gained

7 For a more detailed description of this question, see Samson, 2011 and Lagarde, 2012. 
wide popularity. The application also stressed the fact that the "concerned community" was "the entire population of Reunion" and that maloya had become the "emblem of Reunion culture," "the very symbol of a cultural identity that spanned generations." ${ }^{\prime 8}$ However, the absence of a true, broad-based consensus on this question has pervaded the cultural environment of the island ever since the 1970s, a point of contention that was given new energy during the dissension surrounding the recognition of maloya by the ICH.

To fully understand this conflict, it should be kept in mind that the international recognition of maloya was interpreted locally, in a manner consistent with the arguments contained in the application, as cementing its status as the musical emblem of Reunion. The question of the "risk of extinction" was not part of the criteria for joining the representative list as defined in the 2003 Convention. Maloya, one musical form among others on Reunion Island, was thus awarded a specific symbolic value linked to cultural representativeness by the press following its official selection. In the cultural and political environment of Reunion, displacing the question of representativeness in the direction of the question of a "national" symbol further fueled the ensuing conflict involving maloya. In particular, it helped drive the competition for representativeness between maloya and séga. The reactions in the press during the days following the announcement offer ample evidence of this shift in emphasis. On October 2, 2010, Bernadette Ladauge, an influential figure in Reunion's folklore scene for the past forty years, declared in the Journal de l'Tle de La Réunion:

"What amazes me is to see only maloya and not séga listed as heritage by UNESCO. Maloya, historically, is séga [...]. That's how we called the slaves' dances. [...] Séga presents the basic rhythmic pattern of our music, and you distinguish maloya from it just through a difference in tempo."

8 This dossier can be consulted on the UNESCO site at: http://www.unesco.org/culture/ich/index. php?RL=00249\&topic=desc. In his analysis of this dossier, Benjamin Lagarde emphasizes the fact that maloya was the focus of a "new definition" that alternated between "Black individualist' and 'Creole unitarian' points of view" (Lagarde, 2012: 130). He reveals the highly political and identity-related character of this kind of application.

9 Because Reunion is officially a department of France, it could be argued that it is inappropriate to refer to "national" representativeness in the case of maloya. However, the local debates that accompanied the MCUR project and the inclusion of maloya in the ICH were not framed by the fact that the island is a region belonging to France, but by the notion of the particular insular identity of the island. 
Conversely, there was this reaction from a well-known maloya musician and militant:

"Great! This is what we were hoping for [...]. It [maloya] should be everywhere in Reunion, just as séga is everywhere on Mauritius ${ }^{10}[\ldots] . ”$

The initial reaction centers on the historic links between maloya and sé$g a$ and underscores the fact that, despite differences in terminology, maloya is allegedly a sub-category of séga, which is therefore its source. The second reaction dodges the question of the presence of séga on the island while insisting on the importance of the practice on Mauritius as well. The elevation of the status of maloya also called into question, if less officially, the role of musics associated with popular Hinduism in the musical representativeness of the island. During a conference which I had the opportunity to organize as part of the commemoration ceremonies surrounding the date of the abolition of slavery in 1848 , the director of a concert hall raised this issue when he publicly stated that:

"People always say that maloya is side-lined, forgotten, neglected, criticized. But the music that is totally absent from the cultural scene of Reunion, and has been for a long time, is the music connected to the population's Indian roots, and in particular the bal tamoul ${ }^{11}$. But we the malbars, ${ }^{12}$ we do not complain about it...”

In another context, a militant Hindu priest from the western part of the island exhorted the public, at a bal tamoul I attended, to invest themselves more in transmitting this heritage so that the malbars would not be considered "nobodies," and so that maloya would not be viewed as "THE Reunion culture and ALL OF Reunion culture." In light of this handful of selected responses, it is worth wondering about the notion of representativeness and the interpretations surrounding it. The discussion of maloya international recognition thus appears to have been framed more as a conversation about the island's musical representativeness (an “emblem” effect of its recognition

10 Mauritius is an independent nation formed by islands, $170 \mathrm{~km}$ away from Reunion.

11 A form of popular theater of Indian origin in which passages of the Mahabarata are performed on stage.

12 Descendants of Indians. 
by the ICH) than within the context of a consideration of Reunion's overall contribution to the Intangible Cultural Heritage of Humanity.

\section{Conclusion}

Unlike the situation in Reunion, there was never any doubt in Brazil about which genre should be considered the nation's "musical emblem.” And although this distinction was already assigned to samba in the version that had evolved in Rio de Janeiro since the 1930s and had become widespread throughout the country, the ICH Proclamation of Masterpieces emphasized the "risk of extinction" as opposed to the emblematic nature of the candidates. Still, the first choice of the Brazilian Ministry was to present the musical genre already chosen by Brazilians as the most representative. This initial choice ensured that the final candidate was the only one that could enjoy national recognition "obliquely" while also satisfying the requirement that it face a "risk of extinction."

But the former Proclamation and the more recent Representative List do not in any way constitute a list of "the most representative genres" or the most emblematic musics of the affected countries. If Hafstein's analyses (2004) are correct, national representativeness does not in fact constitute a determining feature of the 2003 Convention, which is centered on strengthening "communities" among UNESCO member-states. Even if the intentions of UNESCO legislators, in such expressions as "Masterpieces of ICH" and "ICH Representative List," were not to locate "the most representative" candidates in each country, the cases we have analyzed of samba and maloya suggest the extent to which this system was interpretable within the framework of political and identity-based choices. Practitioners and experts in search of recognition, as well as militants, government civil servants, and administrators of regional institutions all appeared to have internalized, more or less willingly, the ICH program as part of collective, identity-related self-celebrations. This reinterpretation of the regulations associated with promoting the values of ICH can vary enormously depending on local political and cultural contexts, as we hope this article has shown. Even when the "successful" candidates share numerous formal and historical traits, like samba de roda and maloya, it is clear that precise, thoughtful, case-by-case analysis remains the only means of evaluating the impact-positive and/or negative- of 
international programs for safeguarding particular cultural expressions.

Translated from the French by John Angell

(The authors would like to thank Michael Iyanaga for his suggestions and remarks on the English version.)

Accepted for publication on February 22, 2013.

\section{References}

ALVES, Bernardo. 2002. A pré-história do samba. Petrolina (PE): Ed. by author. BOURDIEU, Pierre. "Le point de vue de l'auteur. Quelques propriétés générales des champs de production culturelle", In: Les règles de l'art: genèse et structure du champ littéraire. Paris: Seuil, 1998.

CHAUDENSON, Robert. 1974. Lexique du parler créole de La Réunion. Paris: Honoré Champion.

FREYRE, Gilberto. 1963 [1933]. The masters and the slaves. New York: Knopf.

HAFSTEIN, Valdimar. 2004. The making of intangible cultural heritage: tradition and authenticity, community and humanity. Unpublished Doctoral Dissertation, Berkeley, University of California.

LAGARDE, Benjamin. 2012. Réunion Maloya. La créolisation réunionnaise telle qu'entendue depuis sa musique traditionnelle, Unpublished Doctoral Dissertation, Université de Provence.

LA SELVE, Jean-Pierre. 1995 [1984]. Musiques traditionnelles de La Réunion. Saint-Denis: Azalées Éditions.

LOPES, Nei. 1992. O negro no Rio de Janeiro e sua tradição musical. Rio de Janeiro: Pallas.

MANUEL, Peter. 1988. Popular musics of the non-western world. New York: Oxford University Press.

MARIMOUTOU, Carpanin \& Françoise VERGES. Pour un musée du temps présent. La Maison des Civilisations et de l'Unité Réunionnaise. Digital version consulted online on 20 avril 2013: http://www.temoignages.re/IMG/pdf/ MCUR_POUR_UN_MUSEE-2.pdf

RIBEIRO, Darcy et al. 1996. Mestiço é que é bom! Rio de Janeiro: Revan. RODA, Jessica. 2011. "Des judéo-espagnols à la machine unesquienne. Enjeux et défis de la patrimonialisation musicale," Cahiers d'Ethnomusicologie, 24: 
123-141.

SANDRONI, Carlos. 2001. Feitiço decente: transformações do samba no Rio de Janeiro, 1917-1933. Rio de Janeiro: Jorge Zahar Editor / Editora UFRJ.

SANDRONI, Carlos. 2010. "Samba de roda, patrimônio imaterial da humanidade”, Estudos Avançados, 24(69): 373-388.

SANDRONI, Carlos. 2011. "L'ethnomusicologue en médiateur du processus patrimonial: le cas du samba de roda". In: Chiara Bortolotto (org.), Le patrimoine culturel immatériel: enjeux d'une nouvelles catégorie. Paris: Maison des Sciences de l'Homme. pp. 233-252.

SAMSON, Guillaume. 2008. "Histoire d'une sedimentation musicale”. In: G. Samson, B. Lagarde, C. Marimoutou (orgs.), L'univers du maloya. SaintDenis: Editions de La DREOI. pp. 10-88.

SAMSON, Guillaume \& DESROCHES, Moniques. 2008. "La quête d'authenticité dans les musiques réunionnaises”. In: C. Ghasarian (ed.), Anthropologies de La Réunion. Paris: Edition des Archives Contemporaines. pp. 201-218.

SAMSON, Guillaume. 2011. "Le maloya au patrimoine mondial de l'humanité. Enjeux culturels, politiques et éthiques et culturels d'une labellisation”, Cahiers d'Ethnomusicologie, 24, p.155-169.

SCHWARCZ, Lilia Moritz. 1993. O espetáculo das raças: cientistas, instituições e questão racial no Brasil do século XIX. São Paulo: Cia. das Letras.

SKIDMORE, Thomas. 1993. Black into white: race and nationality in Brazilian thought. Durham: Duke University Press.

UNESCO. Dossier de candidature du maloya. Digital version consulted online on April 26, 2013: http://www.unesco.org/culture/ich/index. php?RL=00249\&topic $=$ desc.

UNESCO. 2001. "Proclamation of masterpieces of the oral and intangible heritage of humanity: guide for the presentation of candidature files." Paris: UNESCO. Digital version consulted online on April 26, 2013: http:/| unesdoc.unesco.org/images/oo12/0o1246/124628eo.pdf

VIANNA, Hermano. 1995. O mistério do samba. Rio de Janeiro: Jorge Zahar| UFRJ.

WADDEY, Ralph Cole. 1980. "Viola de samba and samba de viola in the Recôncavo of Bahia, Brazil", Latin-American Music Review / Revista de Música Latinoamericana, 1(2): 196-212. 